\title{
WALKING AND DWELLING: MAKING A DAILY PROVOCATION, BUILDING A COMMUNAL PLACE AND BECOMING AN ARTIST IN RESIDENCE
}

Kwang Dae CHUNG *

Department of Curriculum \& Pedagogy, Faculty of Education, University of British Columbia, Canada

\begin{abstract}
This visual essay incorporates the researcher's own a/r/tographical living inquiry into her daily walk. Through her daily walking experience, the researcher created different provocations in order to answer the question. "How might it be possible to make time to experience being in the moment and dwelling with the natural materials whilst walking?" This research took the form of a selfstudy in which she reflected on her own daily walking and provocation journal. The researcher used two forms of arts-based research methodology; "a/r/tography as living inquiries" and "aesthetic-based research (ARB) as pedagogy". In order to find answers to the research question, the researcher committed herself to being and dwelling, in inquiries, and to allow herself to maintain an open mind. Through this living inquiry, the researcher learned how an act of "commitment" (ongoing living inquiry) and "contiguity" helped her to understand the importance of "the relationship between art and graphy, that is between the art form and writing within or about the phenomenon". This relational inquiry enabled her to locate herself "in the space of the inbetween to create self-sustaining interrelating identities that inform, enhance, evoke and/or provoke one another" and to become an A/r/tographer. In conclusion, this research impressed upon her the profound value of living inquiries and being in lived experiences because it has given her an awareness of the impact of the process rather than the outcomes.

Keywords

A/R/Tography, Living Inquiry, Artistic Provocation, Tree Stump, Springy.
\end{abstract}

\section{Introduction}

Walking in the forest and realizing its potential requires more of our bodies than simply the repetitive motion of moving one foot in front of the other. The act of walking can incorporate all of our senses in addition to the use of our legs. When I go for a walk, I open my eyes to see the world; I tune my ears to listen to the sounds water, the wind and the birds. I inhale through my nose in order to smell the sun, rain and earth. I use my body and my mind to feel and to be aware of the air. Triggs \& Irwin (2014) describe how "walking was at one time the only means capable of modifying the environment and continues today, to be an aesthetic method of making oneself feel at home on the earth" (p.22). I contemplate how I can "feel at home" when I walk in the forest. On each of my walks, I attempt to attune myself to the space, the environment and the natural materials around me; as well, I seek a sense of belonging in nature. One day toward the end of the summer of 2018, I went for my habitual morning walk along a trail during which I came to a familiar a small bridge with a handrail, on which I spotted five little rocks. They were lined up perfectly; the row of rocks was barely noticeable and yet it caught my attention. I received the invitation from those five little rocks to experience being in

*Corresponding author: edcp.educ@ubc.ca 
the moment and dwelling with the materials. Truman and Springgay (2016) state "Walking also provides a way to open up the non-visual senses, finding ways of knowing and communicating through movement, and helps to de-familiarize everyday actions” (p.261). The five little rocks helped me to de-familiarize my everyday walking. I stopped and contemplated a possible story behind the row of rocks. Who had placed the rocks then? Why did that person do so? Who else would notice the five little rocks? Nowadays, it is not at all uncommon to see people glued to their phones. These people are generally oblivious to what their toddler may be doing or communicating from their stroller, the whereabouts of their dogs or what is happening in the immediate environment. Their lack of awareness has caused me to wonder how I could entice these same people away from their devices to pause and experience a sense of wonder in a given moment. How would it indeed be possible to press the pause button amidst the frantic busyness of life and simply experience mindfulness?

My intention in this project is by creating and recreating daily artistry, how is it possible to provoke others to attentively stop and react to my invitations? I am also interested in my invitation will provide experiences of being and dwelling in the moment among others. Furthermore, I have been wondering how I may respond to and dwell in my own artistic evocations and provocations. Kind (2017) asserts "Dwelling is about being immersed in the currents of the lifeworld..., the idea of dwelling takes into account processes of working with materials and not just doing something to them" (p.9).

With these thoughts in mind, I have started to incorporate my own a/r/tographical living inquiry into my daily walk. " $\mathrm{A} / \mathrm{r} /$ tography is active and responsive: It requires attentiveness to what is seen and known and to what lies beneath the surface" (Springgay, Irwin \& Kind, 2005, p.905).

\section{A/r/tography as living Inquiry}

According to Irwin (2013), a/r/tography is "a form of practice-based research that recognizes making, learning, and knowing as interconnected within the movement of art and pedagogical practice" (p.37). A/r/tography (Iwrin, 2008) is the process of living inquiry. The a/r/tograpical living practice is not about finding answers and acquiring knowledge. It is an ongoing process of wondering and "questioning where artistic contexts, materials and processes create transformative events, interactive spaces in which the reader/ viewer/ audience can co-create in meaning-making" (LeBlanc, \& Irwin. 2018, p.3). A/r/tography allows artists, researchers and educators to invite others to engage with each learning process, to enter aesthetic spaces alive with potential for wonder and discovery, and to emphasize the emergence and what is being learned through this emergence (Springgay, 2008).

My intention in this project is to find a means through creating and recreating daily artistry in 
a particular space, which has become an outdoor atelier, to provoke others to stop attentively and react to my invitations. Furthermore, I want to explore the extent to which others' reactions may in turn provoke me to recreate my daily artistic provocation.

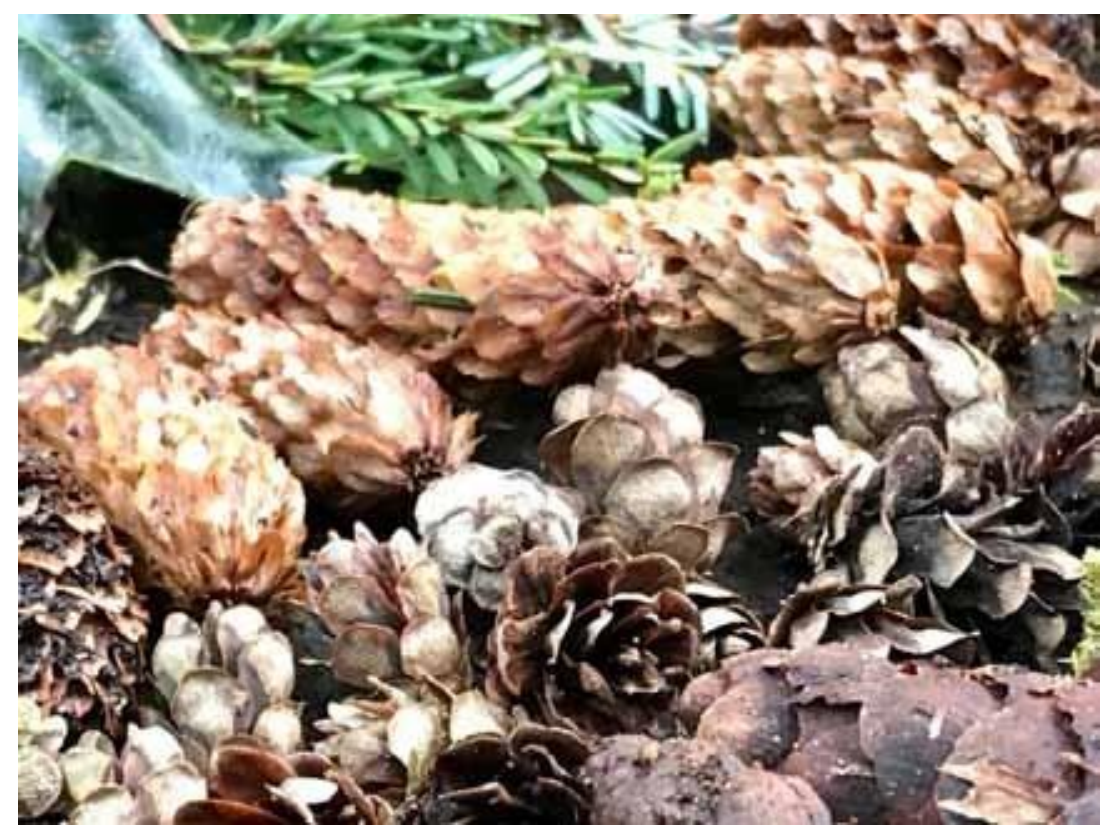

Walking: making and provoking

Provocation 1: Provoking and being provoked; acting and reacting

I begin making my artistic provocations by collecting natural materials that I am able to find on a trail where I walk daily. At the beginning of this project, my natural materials are primarily fall leaves. I mainly place them on a tree stump which serves as my canvas as well as on the ground nearly where tree roots grow and people walk their dogs. As the tree stump is round, I make a circle with the leaves and as the ground is uneven, I make a flowing river with leaves and wooden sticks. At the beginning of this art making process, there is often barely a trace of the circle of leaves, or of any of my artistic provocations the following day. I am often uncertain as to how to react upon discovering the disappearance or a partial destruction of my artistic provocation. I sometimes react to the anonymous actions immediately. However, I often respond to the reaction namely the disappearance or partial destruction of my art piece, a few days later. Each time my artwork on the tree stump is broken, or destroyed, I issue a fresh invitation on and around the same tree stump and on the surrounding ground. Every time I finish making a fresh invitation, I wonder if this one will also be destroyed soon, or if it will remain intact for a while. Triggs and Irwin (2014) emphasize the movements of action and reaction.

In walking, multidimensional movement cannot be spatialized; its essential character is always 
in a state of becoming. This means that one experience always recedes into other experiences and simultaneously we feel anticipation and remembrance, approach and withdrawal, recovery and loss. Because most of our actions are re-action (P.29).

After a few months of continuous provocative art making in the same space, destructive reactions from others have decreased significantly. Occasionally, I note how others have contributed to my art works, or I see additional art works created alongside my own artistic work. Changes to or the disappearance of my art works may result from natural phenomena, animals or people. No matter how many times I see provocative reactions from others, even in a public space, I feel a sense of frustration. However, I have to accept all reactions from others as these result from their acceptance of my invitation to stop and dwell in the moment. Consequently, I am frustrated with my own frustration. Springgay, Irwin, and Kind (2005) contend that any acts of engagement will occur in-between opening spaces whereas knowing is situated within the middle and on the edges. I should therefore regard these open spaces which occur within the disruptive actions as invitations "that leave room for encounters between artist/ researcher/ teacher and reader/viewers entangling experience(s)" (Springgay, Iwrin \& Kind, 2005, p. 906).

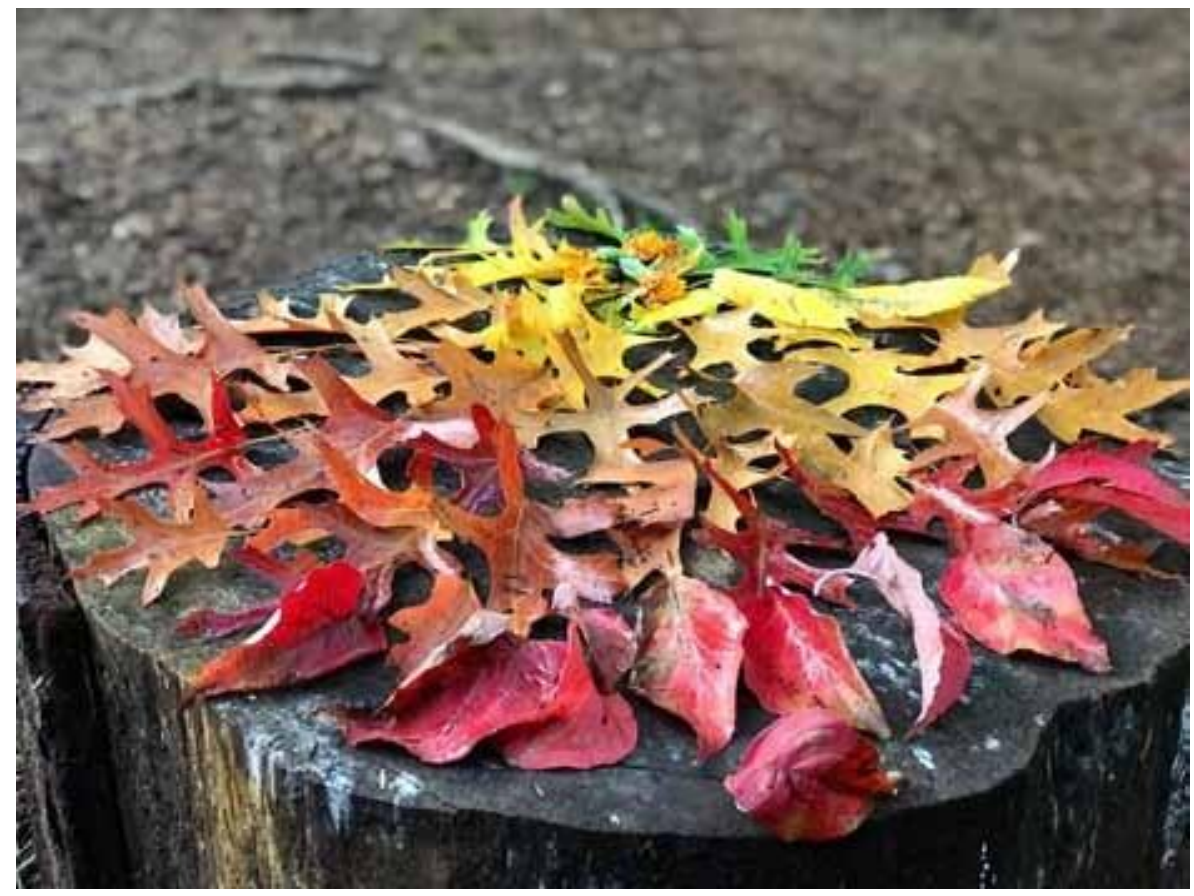

Dwelling in the midst of leaves

Today, some of the yellow and green leaves were still there, but the shape was a little different. How could I react to this?

I chose not to fix it. 
I chose not to sweep the remaining leaves from the stump.

Today, I did nothing.

(Excerpt from my daily journal)

Returning to play with wood sticks... the leaves are gone

Not one of my leaves remained on the stump today.

"The urge to destroy is also a creative urge" (Picasso).

Repetition of creating and recreating, acting and reacting.

What kind of action will come next?

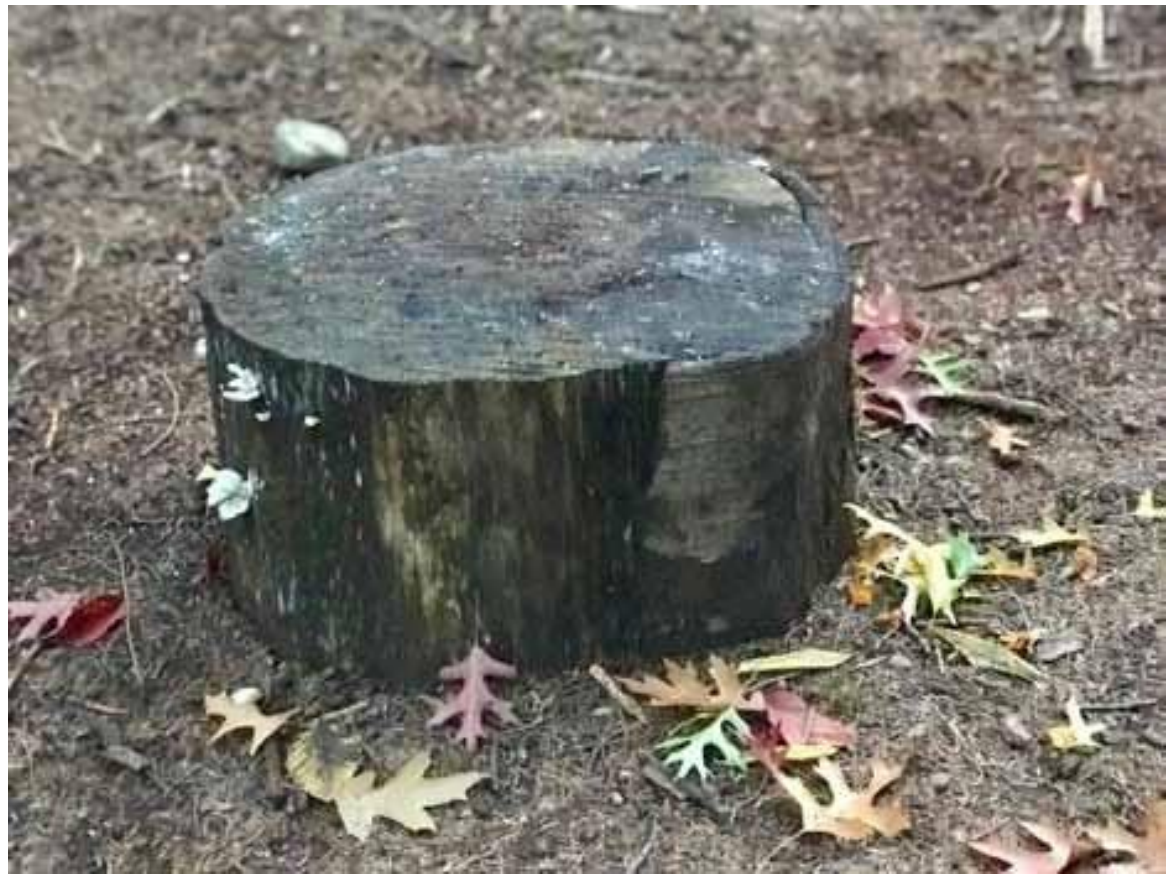

Within the in-between open space where both viewers and $\mathrm{a} / \mathrm{r} /$ tographers coexist, I repeatedly act and react to re-provocations from others as well as my own provocative art, and keep questioning, wondering, being and dwelling. LeBlanc and Irwin (2018) support my experience and argue that "the provocation calls the inquirer to action; to navigate through/with/in the complex processes that reflective, reflexive, recursive, responsive, and/or embodied modes of questioning and questing require” (p.13). These modes of ongoing questioning, questing, being and dwelling allow me to continuously move to the next level of as an artist, a researcher, a teacher and a learner rather than remaining with the same perspective and position. Andy Goldsworthy, British nature artist, speaks about actions of questioning and questing in regard to his own art works, You think: What else is here? What else can I see? Suddenly you find something that is so big and so obvious that you wonder, how did I miss it? You realize that you're still not seeing much, there's always more to be seen and understood (Artsy, 2018). 
To answer my own question, I am required to hold the a/r/tograpical rendering (Springgay, Irwin \& Kind, 2005, p. 909) which offers the possibility of creating meaning, deep understanding of what it is, is not, and what it might be; as well as disrupting others beliefs, thoughts and ideas (LeBlanc \& Irwin, 2019; Springgay, Irwin \& Kind, 2005).

Provocation 2: Becoming a nature artist and building a communal outdoor atelier through dialogue Becoming a Nature Artist

Walking in the rain Looking for life and cheer Picking Autumn leaves.

The multitude of colours inspire me to paint the top of my wood stump.

My hand becomes a paint brush, the leaves, my paints and the tree stump, my canvas.

A lady walks by, looked at my painting and exclaims, "From now on, I am going to call you, 'a nature artist!'”,

When I step back and look at the space, I realize this space has become my outdoor atelier and a communal space for all.

I am now becoming an artist in residence in my outdoor atelier.

(Excerpt my daily journal)

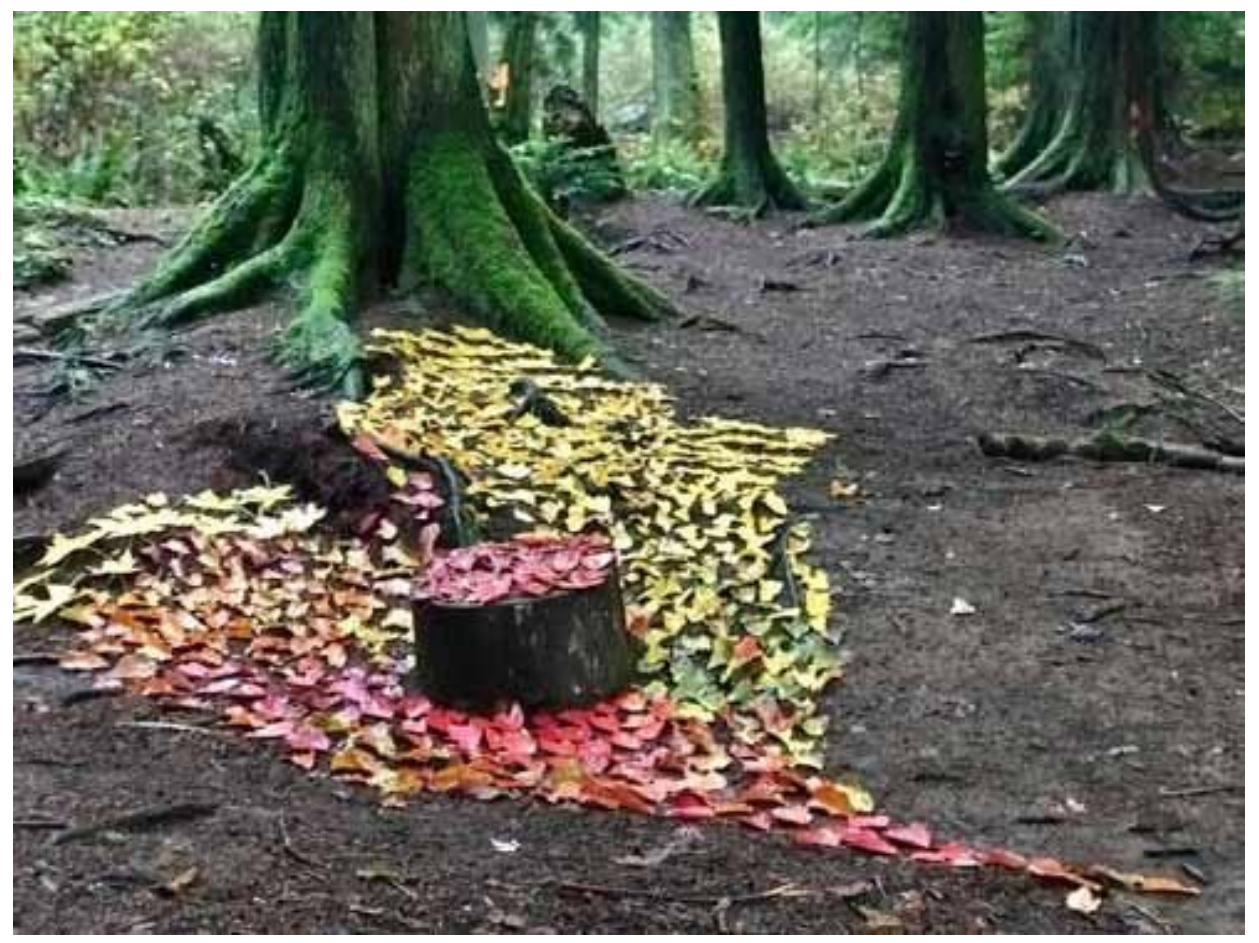

To explore the meaning of living inquiries, Irwin (2008) asks "How might we prepare ourselves to be personally engaged?" (p.75). Irwin (2008) believes that a/r/tographers should continuously keep exploring their abilities, curiosity and ideas and be committed to art practices and their own inquiries as they continue to be learners, researchers and artists. $\mathrm{A} / \mathrm{r} /$ tographers also need to share a sense of being with others, their learning processes, 
strategies and sense of wonder. Through my daily provocation, artistic creations, I continually ask myself how I provoke others to stop and wonder when they see my provocation. I do not necessarily expect others to like my artistic creation through my provocations, but I keep pursuing others as they walk and hope they notice something new every day within the space which has become a communal outdoor atelier. Through this ongoing walking research, involving acting and reacting to each other through my art works, I have noticed that an invisible dialogue involved between viewers and myself. According to Kabakov (2004), dialogue does not only happen through verbal communication in human relationships, rather it also exists "between the space of community and the art work(s) that are created for those spaces" (Irwin, Bickel, Triggs, Springgay, Beer, Grauer, Xiong, \& Sameshima, 2008, p.63).

Kabakov (2004) refers to the invisible conversation as "silent dialogue". Irwin (2008) claims that negotiating and renegotiating our personal focus and space within a community of belonging is important. Paulo Freire (1970) stresses how dialogue becomes an encounter of building human relationship with others. Needless to say, I have had many opportunities to have not only silent dialogue but also verbal dialogue with my neighbors, too. Through dialogue with others, I have been reforming my understanding of public art, public space and human relationships. Irwin, Bickel, Triggs, Springgay, Beer, Grauer, Xiong, \& Sameshima, (2008) emphasize, "Places of learning provide opportunities for people to feel the materiality of community and to provide questions and perspectives that can be carried over into other situations in ways that open the future to new possibilities for living and working together" (p.64). The most challenging part for me being an $\mathrm{a} / \mathrm{r} /$ tographer is when people distance themselves from having dialogues with me as well as engaging with my artistic provocations. Irwin (2008) admits freely that it is of course not easy to align our own way of thinking with others. She therefore encourages us to address these impossibilities and difficulties "[by] creating practices that trouble or address difference" (p.79).

Provocation 3: Dwelling, touching, listening, talking and responding to natural materials

Pattering Oak Leaves

I return to the tree stump.

The recent invitation is mostly still there.

I pass by and keep walking.

I come upon an Oak tree.

The ground is covered with brown leaves.

I pay close attention to each leaf and I start noticing multiple autumn colours, so I collect some. I retrace my steps. 
I come back to my tree stump.

I decide to issue a fresh invitation.

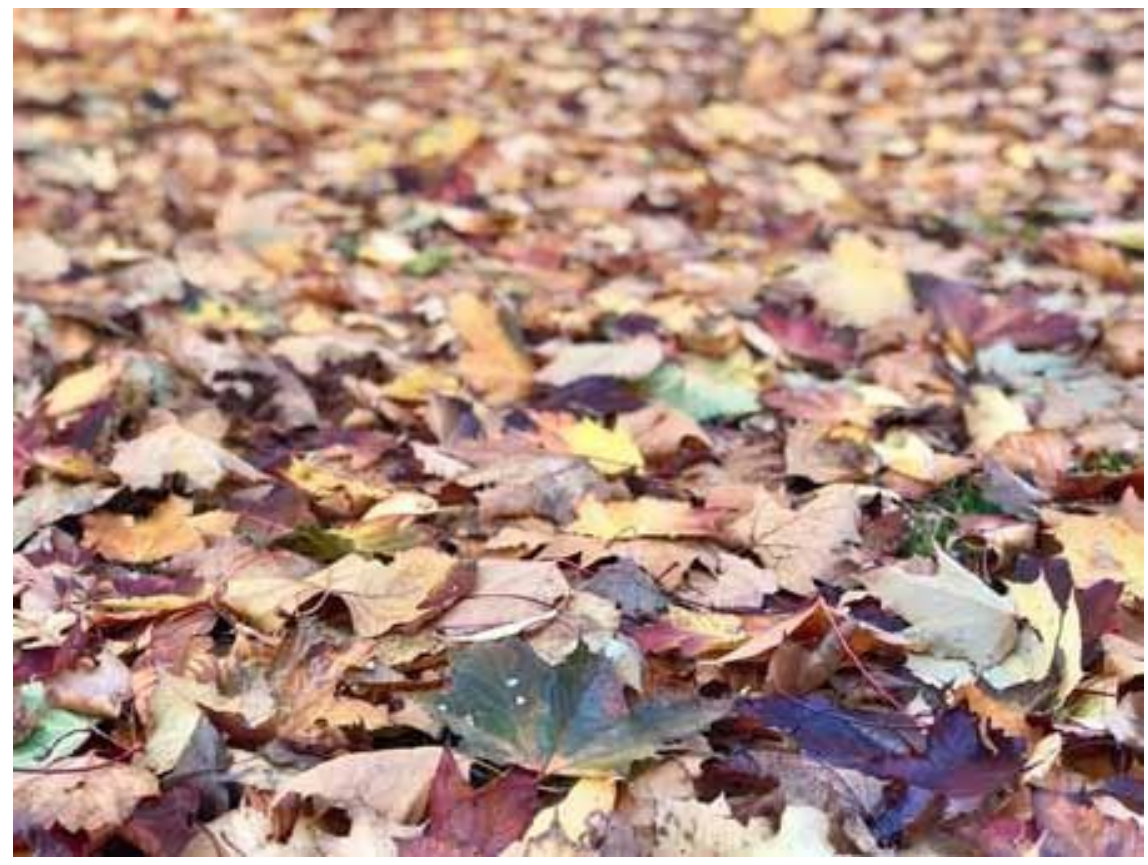

What can I make? (excerpt from my daily journal)

For me to understand what I make, what I see and what I feel at any particular moment in a day, I must be attuned to my body and mind and aware of any encounter with materials that I find as I touch, smell, and listen to them. Springgay (2008) echoes this belief: "to be a body is to be 'with' other bodies, to touch, to encounter, and to be exposed. In other words, each individual body is brought into being through encounters with other bodies" (p.157). In this context, I understand the word, "other bodies" as materials that I encounter. Every time I walk on the trail, I have no fixed agenda. Rather than predicting what may happen and preplanning the day, I keep on open mind to accept what I may meet and discover on the walk and in my outdoor atelier. Pachini- Ketchabaw, Kind, and Kocher (2017) describe paying attention as an invitation to be in wonder, to be open and expose ourselves to the world where we belong. To attend or be attentive is "to linger with, dwell in, [and] take time with" (p.39) the moment in a space within we are given or we chose. It does not mean simply observing things in front of us, rather it means stepping in our tracks and taking our time with the things surrounding us (Pachini-Ketchabaw, Kind, and Kocher, 2017).

Every time, I refresh my artistic provocation in my outdoor atelier, through touching and holding my materials, I first feel the objects and place them in my art work with my hands; I then talk with the materials in order to understand how I can engage with them; as well, how I can maximize the artistic potential of their physical aspects, such as colour, size and shape. In 
addition to reflecting on my own attitude, note how they respond to my touch.

Listening to The Pine Cones Marching Band

I pick up one pine cone and place it on the ground.

It is rough in texture, springy to the touch and fragile.

I pick up another pine cone and place it on the ground It is unique, different, and mischievous. Every time I touch the pinecones, I can hear their voices, saying "hello!"

Every time I feel the pinecones, I can hear their music, playing "Pa rum pum pum pum" I pick up one pine cone and place it on the ground.

Now I can hear the sounds of the pinecones' marching band.

The word, wooden stick, conjure up for most of us the image of a straight piece of woods. However, through working with sticks in my outdoor atelier, I have discovered there are not only straight sticks rather there are also winding, curving, bending, cracking, twisting and twirling sticks. Kind (2017) describes this situation as one, "where (I am) invited to slow down, to listen to the intricate visual and sensorial details, to attend to the particularity or the 'thingness' of things, and to treat things tenderly and gently" (p.9).

LeBlanc and Irwin (2018) discuss how a/r/tography is "conceptualized on the premise that [a] multi-faceted, lived experience and subjective perspective" (p.3) has been transforming from a hermeneutic and phenomenological paradigm to new materialism, and post-humanistic ontology. LeBlanc and Irwin (2018) raise three points relating to materiality, conceptual encounters, and the practice of paying close attention to materials through personal interactions for the purpose of $\mathrm{a} / \mathrm{r} / \mathrm{tographical}$ research.

First, through materials and conceptual encounters, practice pays attention to materials in interaction. It demonstrates how 'thinking in materials' evokes particular invitations and provocations. These provocations extend into the second example, demonstrating how through matter and movement, art practice is a form of ecological inquiry, and third, through becoming medium, the pedagogical process is a participatory, self- reflective process blending performative art practice with dialogic inquiry (LeBlanc \& Irwin, 2018, pp.19-20). 

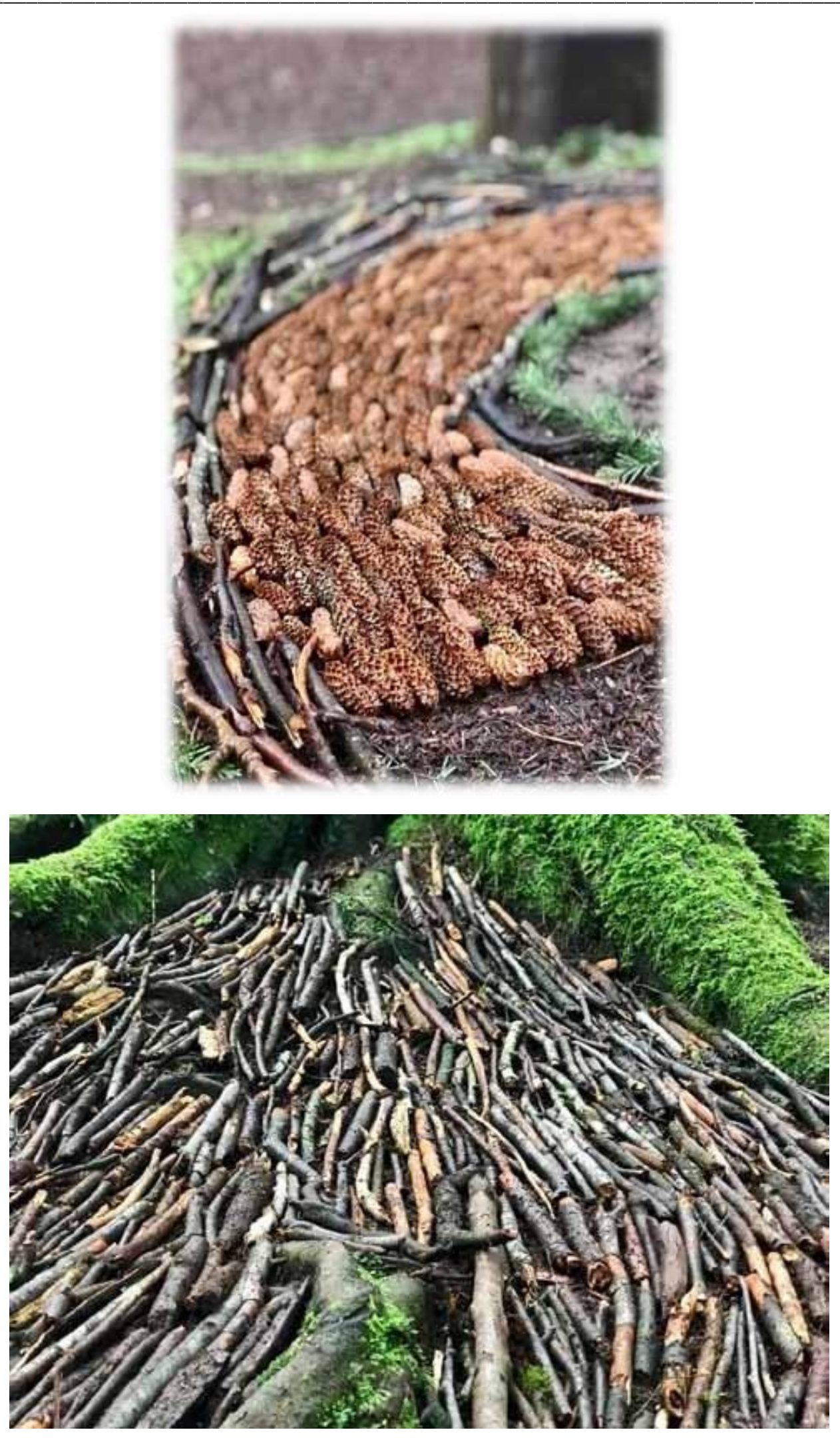

The Story so far...

As a result of conversations and encounters with others, my understanding of provocation has changed and continues to change as a result of my daily walks. My original intended meaning 
when using the word, "provocation" did not include artistic inquiries. However, my provocations have now assumed the form of artistic invitations and as such they constitute communicable languages. Through this communicable language namely artistic inquiries, I have engaged in silent dialogue with natural materials and myself; as well as with my neighbors.

My provocation is no longer a matter of provoking others to stop and wonder at a given moment within the given space. My provocation has been re-provoking and resulting in questions for myself and has allowed me to dwell with the natural materials, the space and time. Furthermore, "De-familialization [in the context of walking] requires us to rethink and re/move what has become habitual, and to re-evaluate or upset common opinion" (Truman \& Springgay, 2016, p.263).

Through this living inquiry, I have learned all daily practices are not end results, but rather deeper understanding of and connecting with experiences along the way.

Furthermore, how acts of rendering (Irwin \&Springgay, 2008) help me understand the importance of "the relationship between art and graphy, that is between the artform and writing within or about the phenomenon" (Irwin \& Springgay, 2008, p.xxviii). This relational inquiry has enabled me to locate myself "in the space of the in-between to create self-sustaining interrelating identities that inform, enhance, evoke and/or provoke one another" (p.xxv) and to become an a/r/tographer. 


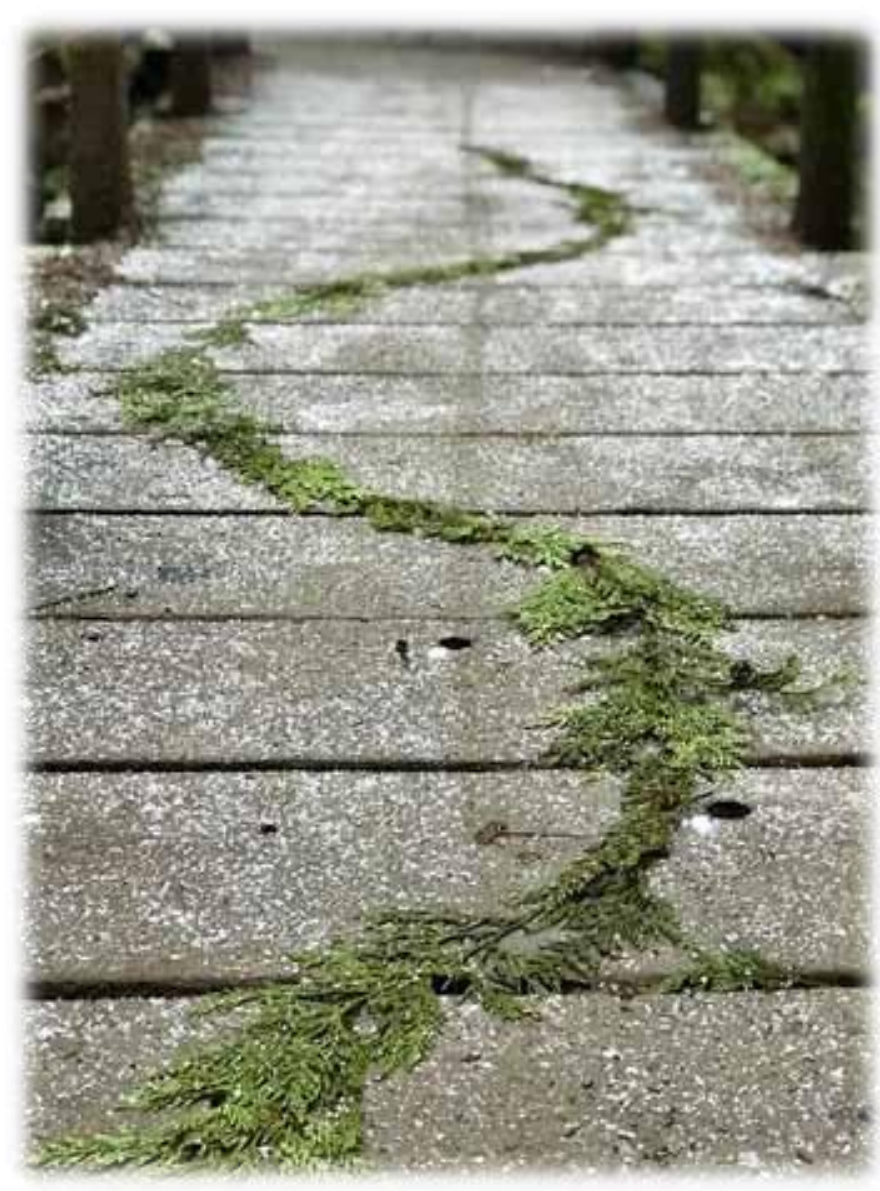

In conclusion, $\mathrm{a} / \mathrm{r} /$ tography is practice based research and more than a means of collecting data and drawing conclusions (Irwin \& Springgay, 2008; LeBlanc \& Irwin, 2018). An a/r/tographer needs to situate him or herself in "the difficult places of in- between ... while situating the in and the through as necessary conditions for the exploring of the new" (LeBlanc \& Irwin, 2018, p.24).

Engaging in this practice, $\mathrm{a} / \mathrm{r} /$ tography inevitably opens many more possibilities for exploring the relationship between theories and living inquiry practices. 


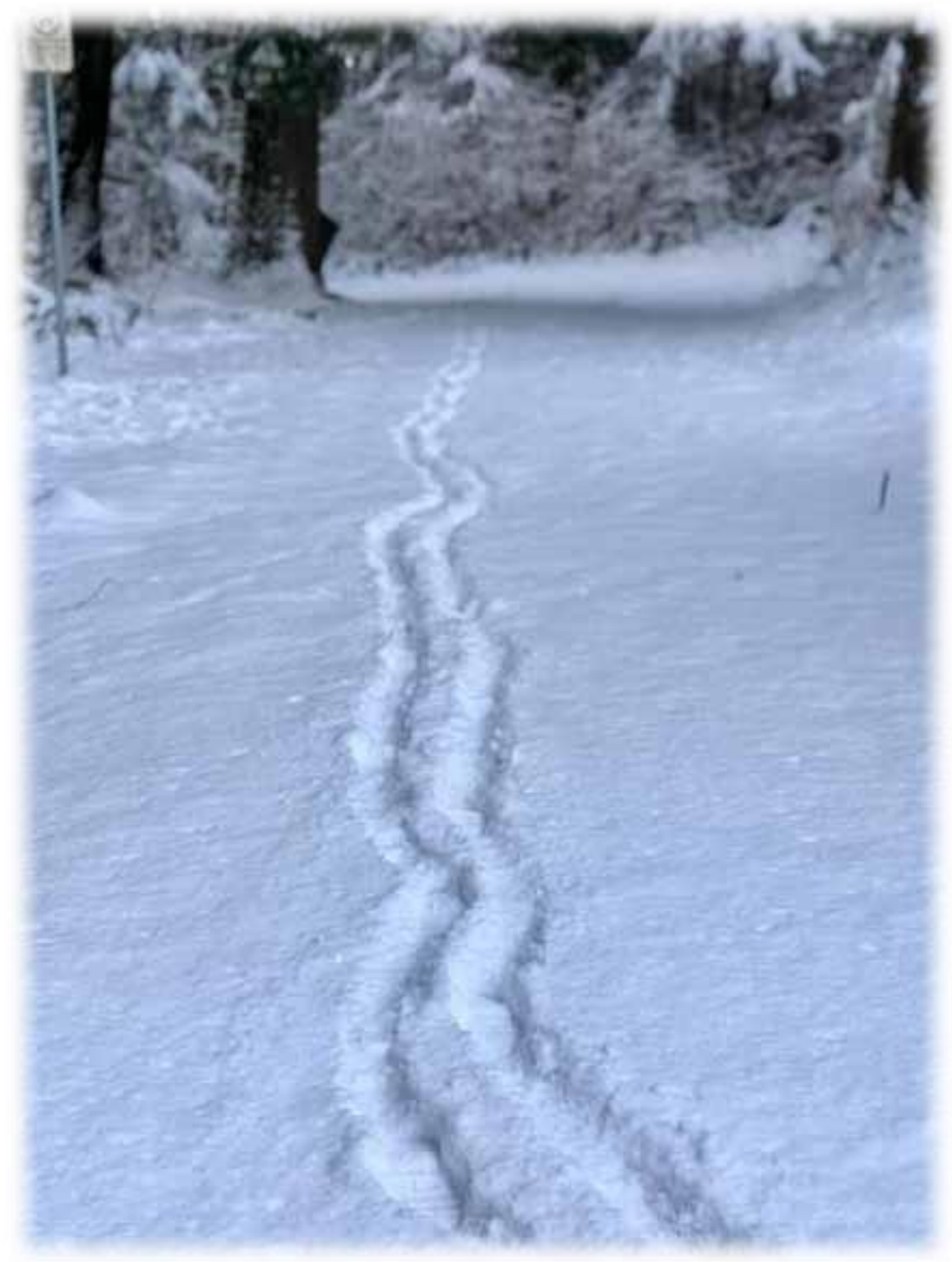

\section{References}

1) Irwin, R. (2008). Community of a/r/tographic practice. In Springgay, S., Irwin, R. L., Leggo,

2) C. \& Gouzouasis, P. Being with A/r/topgraphy (pp.71-80). Rotterdam, Netherlands:Sense.

3) Irwin, R. (2008). A/r/tography as practice-based research. In Springgay, S., Irwin, R. L., Leggo, C. \& Gouzouasis, P. Being A/r/topgraphy (pp.xix-xxxiii). Rotterdam, Netherlands:Sense.

4) Kind, S. (2008). Learning to listen: traces of loss, vulnerability, and susceptibility in art/teaching. In Springgay, S., Irwin, R. L., Leggo, C. \& Gouzouasis, P. Being A/r/tpgraphy (pp.167-178). Rotterdam, Netherlands: Sense.

5) LeBlanc, N. \& Irwin, R. L. (in press). A/r/tography. In Noblit, George (Ed.). Oxford Encyclopedia of Qualitative Research Methods in Education. New York, NY: Oxford 
University Press.

6) Pacini-Ketchabaw, V., Kind, S., Kocher, L. L. M., \& Taylor \& Francis eBooks A-Z. (2017;2016;). Encounters with materials in early childhood education. New York: Routledge.

7) Rousell, D., \& Cutcher, A. (2014). Echoes of a c/a/r/tography: Mapping the practicum experience of pre-service visual arts teachers in the 'Visual Echoes Project'. Australian Art Education, 36(2), 63-76.

8) Springgay, S., Irwin, R., \& Kind, S. (2005). A/r/tography as Living Inquiry through art and text. Qualitative Inquiry, 11 (6), 897-912

9) Springgay, S., Irwin, R., Leggo, C. \& Gouzouasis, P. (2008). Being with a/r/tography

10) Rotterdam: Sense Pub. A/r/tography as practice-based research (pp. xix-xxxiii).

11) Triggs, V., Irwin, R. L., \& Leggo, C. (2014). Walking art: Sustaining ourselves as arts educators. Visual Inquiry: Learning and Teaching Art 3(1), 21-34.

12) Truman. \& Springgay. (2016). Propositions for talking research. In Burnard., Mackinlay., Powell., The Routledge International Handbook of Intercultural ArtsResearch. (pp. 259 267). Routledge, Abingdon.

13) Peisen DING, THE STUDY OF MAERIAL CULTURE FOR ART LEARNING AND MAKING: AN ONGOING JOURNEY WITH A/R/TOGRAPHY, International Journal of Creativity and Innovation in Humanities and Education, Vol. 1 No. 1, 2018, pp. 39-58.

Received: August 17, 2018

Accepted: October 28, 2018 